\title{
Rickettsia sp. Strain NOD Infecting Ticks (Amblyomma nodosum) in an Endemic Area of Spotted Fever in Brazil
}

Author(s): Leonardo Moerbeck, Vinicius F. Vizzoni, Stefan V. de Oliveira, Robson Cavalcante, Gerlene C. B. Coelho, Naylê F. H. Duarte, Marinete Amorim, and Gilberto S. Gazêta

Source: Journal of Wildlife Diseases, 54(2):406-409.

Published By: Wildlife Disease Association

https://doi.org/10.7589/2017-06-137

URL: http://www.bioone.org/doi/full/10.7589/2017-06-137

BioOne (www.bioone.org) is a nonprofit, online aggregation of core research in the biological, ecological, and environmental sciences. BioOne provides a sustainable online platform for over 170 journals and books published by nonprofit societies, associations, museums, institutions, and presses.

Your use of this PDF, the BioOne Web site, and all posted and associated content indicates your acceptance of BioOne's Terms of Use, available at www.bioone.org/page/ terms of use.

Usage of BioOne content is strictly limited to personal, educational, and non-commercial use. Commercial inquiries or rights and permissions requests should be directed to the individual publisher as copyright holder. 


\title{
Rickettsia sp. Strain NOD Infecting Ticks (Amblyomma nodosum) in an Endemic Area of Spotted Fever in Brazil
}

\begin{abstract}
Leonardo Moerbeck, ${ }^{1,2}$ Vinicius F. Vizzoni, ${ }^{2}$ Stefan V. de Oliveira, ${ }^{3}$ Robson Cavalcante, ${ }^{4}$ Gerlene C. B. Coelho, ${ }^{5}$ Naylê F. H. Duarte ${ }^{5}$ Marinete Amorim, ${ }^{2}$ and Gilberto S. Gazêta ${ }^{1,2,6}$ ${ }^{1}$ Programa de Pós-Graduação Stricto Sensu de Biodiversidade e Saúde-Instituto Oswaldo Cruz/Fundação Oswaldo Cruz-Rio de Janeiro/RJ, Brazil; ${ }^{2}$ Serviço de Referência Nacional em Vetores das Riquetsioses-Instituto Oswaldo Cruz/Fundação Oswaldo Cruz-Rio de Janeiro/RJ, Brazil; ${ }^{3}$ Secretaria de Vigilância em Saúde-Ministério da Saúde/MS-Brasília/DF, Brazil; ${ }^{4}$ Secretaria Estadual de Saúde do Estado do Ceará, Baturité, Brazil; ${ }^{5}$ Núcleo de Controle de Vetores-Coordenação de Promoção e Proteção à Saúde-Secretaria Estadual de Saúde-Ceará, Brazil; ${ }^{6}$ Corresponding author (email: gsgazeta@ioc.fiocruz.br)
\end{abstract}

ABSTRACT: Amblyomma nodosum ticks were collected from one collared anteater (Tamandua tetradactyla) in the Caatinga biome, Brazil. From one sample, we isolated a Rickettsia sp. that was phylogenetically close to Rickettsia sp. strain NOD, with 99.9, 100.0, and 99.8\% identity for gltA, htrA, and ompA genes, respectively.

Amblyomma nodosum is a neotropic tick species commonly reported in Brazil. Usual hosts of immature stages are Passeriformes, whereas the giant anteater (Myrmecophaga tridactyla) and the collared anteater (Tamandua tetradactyla) are the hosts of adult stages (Barros-Battestti et al. 2006).

Rickettsia sp. strain NOD (Ogrzewalska et al. 2009), Rickettsia bellii (Moerbeck et al. 2016), and Rickettsia amblyommatis (=Rickettsia amblyommii; Karpathy et al. 2016) are rickettsial organisms known to infect A. nodosum. Although there are no records of human infestations by $A$. nodosum, evidence of rickettsial infections and wide distribution of their host species suggest $A$. nodosum as a potential vector in the enzootic cycle of rickettsiae (Guglielmone et al. 2014). Moerbeck et al. (2016) reported a great diversity of ticks and rickettsiae species in this spotted fever (SF)-endemic area, which has a unique characteristic of being composed of forest fragments within the Caatinga biome, a semiarid region of Brazil. We used our data to analyze the potential participation of $A$. nodosum in the epidemic cycle of SF in the region.

In April 2013, 100 adult tick specimens (79 males and 21 females) were collected from a single collared anteater from the municipality of Guaramiranga $\left(4^{\circ} 15^{\prime} 48^{\prime \prime} \mathrm{S}, 38^{\circ} 55^{\prime} 59^{\prime \prime} \mathrm{W}\right)$, state of Ceará, Brazil, an endemic area of SF. Tick specimens were morphologically classified according to Barros-Battestti et al. (2006). Sixteen samples divided into 24 specimens were tested in pools or individually. Eleven samples were individually tested (six samples with one male each and five samples with one female each); two of the females were partially engorged, and three were completely engorged. Five samples were pooled (one sample contained two flat females, one sample had two males, and three samples had three males each). Samples were submitted to DNA extraction (Aljanabi and Martinez 1997) and conventional PCR targeting rickettsial genes: glt A CS2 region (CS-78 and CS-323) and CS4 region (CS-239 and CS-1069), ompA (Rr190.70F and Rr190.602R), and htrA (Rr1175F and Rr2608R) by using published protocols (Regnery et al. 1991; Blair et al. 2004; Labruna et al. 2004). One sample was analyzed for the cox-1 gene (Folmer et al. 1994). All DNA fragments with expected size were purified by using a DNA Mini Kit (Real Genomics, New Taipei City, Taiwan), and an automated ABI 3730xl DNA analyzer (Applied Biosystems, Foster City, California, USA) was used to sequence the DNA in both directions (Otto et al. 2008). Phylogenetic analysis was performed with a concatenated sequence by using neighbor-joining methods (MEGA 5.2, Tamura et al. 2011) and the Kimura two-parameter model to estimate genetic divergency (Kimura 1980). Bootstrap values were obtained from 1,000 randomly generated trees. Sequences gener- 
ated in this study were deposited in GenBank (accession no. KY660046-48).

All ticks were morphologically identified as A. nodosum. The sequence of cox-1 that we obtained was $99.4 \%(654 / 658)$ similar to $A$. nodosum voucher CAS-T028 (accession no. KF200111). All analyzed samples were positive for at least the CS2 fragment of glt A gene. The PCR reactions with sample LIC4363I were positive for all primer sets, producing amplicons of expected size. The BlastN analysis (National Center for Biotechnology 2018) showed that gltA, htrA, and ompA sequences were $99.9 \%(1,055 / 1,056), 100.0 \%$ (394/394), and 99.8\% (490/491) similar to Rickettsia sp. The NOD sequences (accession nos. EU567177, EU567178, and EU567180, respectively). To improve the phylogenetic analysis, all gltA (1,053 base pair [bp]), htrA (394 bp), and ompA (463 bp) sequences were concatenated $(1,910 \mathrm{bp})$. The resulting tree corroborated with BlastN analysis and showed the bacterium was closely related to Rickettsia sp. NOD (Fig. 1).

In our study, morphologic identification was corroborated by molecular analysis, confirming that the tick species responsible for parasitizing of the anteater was A. nodosum. In addition, the tick was infected with Rickettisa sp. NOD, as previous studies reported (Ogrzewalska et al. 2009). This rickettsial organism may infect diferent tick species; however, it frequently infects $A$. nodosum, which has a wide distribution in Brazil (Ogrzewalska et al. 2009). Although our study area somewhat resembled the Atlantic rainforest biome, it actually is a semiarid region.

Amblyomma nodosum has been widely reported in the Americas: Argentina, Bolivia, Brazil, Colombia, Costa Rica, Guatemala, Mexico, Nicaragua, Panama, Trinidad and Tobago, US, and Venezuela (Barros-Battestti et al. 2006; Mukherjee et al. 2014). In Brazil, it is reported in 11 states (Espírito Santo, Goiás, Mato Grosso, Mato Grosso do Sul, Minas Gerais, Paraná, Rio de Janeiro, Rio Grande do Sul, Rondônia, Santa Catarina, and São Paulo) that encompass three biomes (Atlantic Forest, Cerrado, and Pantanal;
Barros-Battestti et al. 2006). Our report extends the distribution of this tick species into Ceará, northeastern Brazil, and within the Caatinga biome, mature stages of $A$. nodosum parasitized T. tetradactyla, which is consistent with previous studies (BarrosBattestti et al. 2006). There is no record of human infestation by A. nodosum (Guglielmone et al. 2014), but it has been previously reported parasitizing a dog (Canis familiaris; Mazioli et al. 2012). Our results may indicate the possibility for epidemic and enzootic cycles of rickettsiae. Immature stages of this arthropod have been reported parasitizing birds (Passeriformes; Ogrzewalska et al. 2009). Although we did not collect birds, their role as spatial dispersers of potential vectors of rickettsia must be considered, because that would facilitate the establishment and circulation of species of rickettsia in new areas (Ogrzewalska et al. 2009). Thus, immature stages of A. nodosum may be important for increasing the dispersion of Rickettsia sp. NOD, whereas mature stages would serve to maintain this bioagent in an area.

Amblyomma nodosum lives in preserved or minimally anthropically impacted areas, as do its vertebrate hosts (Ogrzewalska et al. 2009). This scenario may explain the species presence in a fragment of Atlantic rainforest within the Caatinga. Thus, the dispersion of immature stages by birds and the colonization of new areas by adult specimens on anteaters may contribute to the establishment of its enzootic cycle in forest fragments.

Funding was provided by Coordenação de Aperfeiçoamento de Pessoal de Nível Superior for the scholarship of L.M. We thank Nicolau Maués da Serra-Freire (in memoriam), Ministério da Saúde, $4^{a}$ Coordenadoria Regional de Saúde da Secretaria Estadual do Estado do Ceará, Núcleo de Controle de Vetores-Coordenação de Promoção e Proteção à Saúde-Secretaria Estadual de SaúdeCeará, and Plataforma Genômica de Sequenciamento (RPT01A) - Fundação Oswaldo Cruz for DNA sequences. 


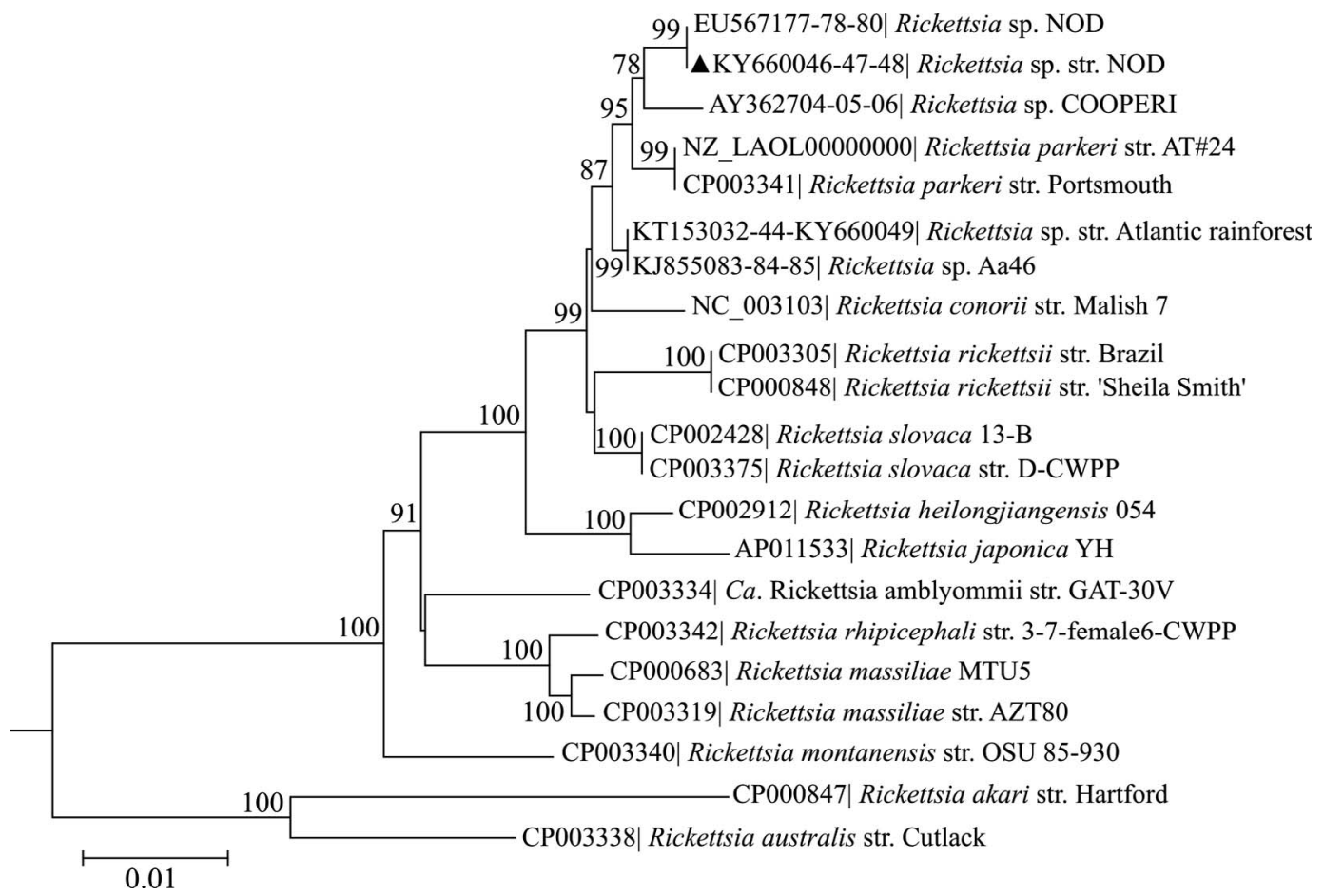

Figure 1. Phylogenetic tree of concatenated spotted fever group rickettsia gltA, htrA, and ompA genes constructed by neighbor-joining method with the Kimura two-parameter evolution model. GenBank accession nos. are presented at the beginning of each rickettsial species. The numbers at nodes are the bootstrap values obtained from 1,000 resamplings. Bootstrap values below $70 \%$ are not presented. The triangle indicates the sequences obtained in this study from a Rickettsia sp. that was phylogenetically close to Rickettsia sp. strain NOD obtained from ticks (Amblyomma nodosum) recovered from the collared anteater (Tamandua tetradactyla) in northeastern Brazil.

\section{LITERATURE CITED}

Aljanabi SM, Martinez I. 1997. Universal and rapid saltextraction of high quality genomic DNA for PCRbased techniques. Nucleic Acids Res 25:4692-4693.

Barros-Battesti DM, Arzua M, Bechara GH. 2006. Carrapatos de importância médico-veterinária da região neotropical: Um guia ilustrado para identificação de espécies. Instituto Butantan, São Paulo, Brazil, 223 pp.

Blair PJ, Jiang J, Schoeler GB, Moron C, Anaya E, Cespedes M, Cruz C, Felices V, Guevara C, Mendoza L, et al. 2004. Characterization of spotted fever group rickettsiae in flea and tick specimens from northern Peru. J Clin Microbiol 42:4961-4967.

Folmer O, Black M, Hoeh W, Lutz R, Vrijenhoek R. 1994. DNA primers for amplification of mitochondrial cytochrome c oxidase subunit I from diverse metazoan invertebrates. Mol Mar Biol Biotechnol 3:294299.

Guglielmone AA, Robbins RG, Apanaskevich DA, Petney TN, Estrada-Peña A, Horak IG. 2014. The hard ticks of the world: (Acari: Ixodida: Ixodidae). Springer Science, Dordrecht, the Netherlands, 738 pp.
Karpathy SE, Slater KS, Goldsmith CS, Nicholson WL, Paddock CD. 2016. Rickettsia amblyommatis sp. nov., a spotted fever group Rickettsia associated with multiple species of Amblyomma ticks in North, Central and South America. Int J Syst Evol Microbiol 66:5236-5243.

Kimura M. 1980. A simple method for estimating evolutionary rates of base substitutions through comparative studies of nucleotide sequences. $J \mathrm{Mol}$ Evol 16:111-120.

Labruna MB, Whitworth T, Bouyer DH, McBride J, Camargo LMA, Camargo EP, Popov V, Walker DH. 2004. Rickettsia bellii and Rickettsia amblyommii in amblyomma ticks from the State of Rondônia, Western Amazon, Brazil. J Med Entomol 41:1073-1081.

Mazioli R, Szabó M, Mafra C. 2012. Amblyomma nodosum (Acari: Ixodidae) parasitizing a domestic dog in Colatina, Espírito Santo, Brazil. Rev Bras Parasitol Vet 21:428-432.

Moerbeck L, Vizzoni VF, Machado-Ferreira E, Cavalcante RC, Oliveira SV, Soares CAG, Amorim M, Gazêta GS. 2016. Rickettsia (Rickettsiales: Rickettsiaceae) vector biodiversity in high altitude Atlantic 
forest fragments within a semiarid climate: A new endemic area of spotted-fever in Brazil. J Med Entomol 53:1458-1466.

Mukherjee N, Beati L, Sellers M, Burton L, Adamson S, Robbins RG, Moore F, Karim S. 2014. Importation of exotic ticks and tick-borne spotted fever group rickettsiae into the United States by migrating songbirds. Ticks Tick Borne Dis 5:127-134.

National Center for Biotechnology. 2018. Basic local alignment search tool (BLAST). https://www.ncbi.nlm. nih.gov/nucleotide/KY660046.1?report=genbank\&log\$ $=$ nucltop\&blast_rank=2\&RID=8CAKXZJY01R $(g l t \mathrm{~A})$; https:/www.ncbi.nlm.nih.gov/nucleotide/KY660047.1? report=genbank\&log $\$=$ nucltop\&blast_rank $=1 \& \mathrm{RID}=$ 8CCHHRW001R (htrA); https://www.ncbi.nlm.nih. gov/nucleotide/KY660048.1 ?report=genbank\&log $\$=$ nucltop\&blast_rank=2\&RID $=8 \mathrm{CCHHRW001 \textrm {R }}$ (ompA). Accessed February 2018.

Ogrzewalska M, Pacheco RC, Uezu A, Richtzenhain LJ, Ferreira F, Labruna MB. 2009. Rickettsial infection in Amblyomma nodosum ticks (Acari: Ixodidae) from Brazil. Ann Trop Med Parasitol 103:413-425.

Otto TD, Vasconcellos EA, Gomes LHF, Moreira AS, Degrave WM, Mendonça-Lima L, Alves-Ferreira M. 2008. ChromaPipe: A pipeline for analysis, quality control and management for a DNA sequencing facility. Genet Mol Res 7:861-871.

Regnery RL, Spruill CL, Plikaytis BD. 1991. Genotypic identification of rickettsiae and estimation of intraspecies sequence divergence for portions of two rickettsial genes. J Bacteriol 173:1576-1589.

Tamura K, Peterson D, Peterson N, Stecher G, Nei M, Kumar S. 2011. MEGA5: Molecular evolutionary genetics analysis using maximum likelihood, evolutionary distance, and maximum parsimony methods. Mol Biol Evol 28:2731-2739.

Submitted for publication 12 June 2017. Accepted 5 September 2017. 